\title{
Ecology and behaviour of the critically endangered Trinidad piping-guan Aburria pipile
}

\author{
Floyd E. Hayes ${ }^{1,3, *}$, Clifmond L. Shameerudeen ${ }^{2,4}{ }^{\text {, Bryan Sanasie }}{ }^{2,5}$, \\ Brett D. Hayes ${ }^{1,3}$, Carol L. Ramjohn ${ }^{1}$, Floyd B. Lucas ${ }^{1}$ \\ ${ }^{1}$ Department of Life Sciences, University of the West Indies, St. Augustine, Trinidad and Tobago \\ ${ }^{2}$ Department of Biology, University of the Southern Caribbean, Maracas Valley, Trinidad and Tobago \\ ${ }^{3}$ Present address: Department of Biology, Pacific Union College, 1 Angwin Ave., Angwin, California 94508, USA \\ ${ }^{4}$ Present address: 307 Michigan Street, Niles, Michigan 49120, USA \\ ${ }^{5}$ Present address: 4867 Greenfield Dr. Apt. 1, Berrien Springs, Michigan 49103, USA
}

\begin{abstract}
From 1997 to 2001 we studied a group of 6 Trinidad piping-guans Aburria pipile, a critically endangered species, in northern Trinidad. The group occupied a home range of 19 ha in highly disturbed secondary forest and around small farms, and often split into smaller groups. They spent $93.6 \%$ of the time in the forest canopy $>5 \mathrm{~m}$ above ground and only $0.2 \%$ of the time on the ground $(\mathrm{n}=48.1 \mathrm{~h})$. In early morning $(\mathrm{n}=18.7 \mathrm{~h})$, they spent $80.3 \%$ of their time perched alert, $9.3 \%$ preening, 3.9\% flying, 3.6\% walking, $2.4 \%$ feeding, $0.3 \%$ drinking, and $0.1 \%$ perched flapping. In late afternoon $(\mathrm{n}=8.2 \mathrm{~h}$ ), they spent $78.6 \%$ of their time perched alert, $12.8 \%$ preening, $3.7 \%$ walking, $3.0 \%$ feeding, $1.2 \%$ flying, and $0.7 \%$ drinking. At midday, they eluded observation. They foraged mostly on fruits (occasionally leaves or flowers) of 15 species of plants, with Virola surinamensis (Myristicaceae) constituting the primary item (33.3\% of foraging bouts; $n=30)$. They drank water from epiphytic bromeliads. Drumming displays, produced mechanically by the wings in flight, were given intermittently throughout the morning and rarely in the afternoon. Singing occurred intermittently throughout the early morning and late afternoon. The song consisted of 3 to 7 plaintive whistles rising in pitch, delivered by lone individuals averaging 2.7 songs $\mathrm{min}^{-1}$, in bouts of up to $30 \mathrm{~min}$. Soft piping calls were usually given in a social context. Raised crest feathers appeared to be an aggressive display. Piping-guans rarely interacted with other species of birds. They were relatively unperturbed by human disturbance.
\end{abstract}

KEY WORDS: Aburria pipile $\cdot$ Behaviour $\cdot$ Cracidae $\cdot$ Ecology $\cdot$ Trinidad

\section{INTRODUCTION}

The Trinidad piping-guan Aburria pipile, known locally as the 'pawi', is a medium-sized species of the family Cracidae. As its name implies, it is endemic to the island of Trinidad, located off the coast of northeastern South America. It formerly occurred throughout most of the island, except perhaps the drier western portions of the island, but is now confined to north-eastern and southern Trinidad where it is critically endangered (e.g., James \& Hislop 1988, 1997,
Alexander 2002, Hayes 2006, Hayes et al. in press). The biology of the Trinidad piping-guan is poorly known. A pioneering study in 1989 and 1991 of a small group of piping-guans at Grande Riviere, along the north coast of Trinidad, documented several aspects of the piping-guan's ecology and behaviour, including foraging and vocalizations (Alexander et al. 1990, 1992, Alexander 2002). In the present paper we describe in further detail the ecology and behaviour of piping-guans, based on a study from 1997 to 2001 at the same site in Grande Riviere. 


\section{STUDY AREA AND METHODS}

Study area. The study site was located on a small hill bisected by the unpaved Monte Video Road, about $1 \mathrm{~km}$ south of the Paria Main Road in Grande Riviere, a small village along the north coast of Trinidad at $61^{\circ} 49^{\prime} \mathrm{N}, 61^{\circ} 03^{\prime} \mathrm{W}$. Although the study site has been highly disturbed by humans, a small group of pipingguans Aburria pipile has persisted since 1963 according to caretakers Leo and Theresa Marin, who lived atop the hill in a small house surrounded by several sheds, roughly in the centre of the piping-guans' home range. The surrounding forest appeared to be mostly secondary growth, comprised of native broad-leaved tree species festooned with epiphytes, and planted fruit trees including avocado Persea americana (Lauraceae), banana and plantain Musa spp. (Musaceae), citrus Citrus spp. (Rutaceae), mango Mangifera indica (Anacardiaceae), ornamental nutmeg Myristica fragrans (Myristicaceae), papaya Carica papaya (Caricaceae), pomme cythere Spondias dulcis (Anacardiacae), and pomerac Spyzgium malaccense (Myrtaceae). Within $1 \mathrm{~km}$ of the house there were several clearings, including an area of 4 ha in size cleared during the study period, with vegetable gardens attended by local residents who hiked daily from their homes in Grande Riviere. Domestic chickens Gallus gallus fed freely around the house.

Methods. We studied the ecology and behaviour of piping-guans intermittently between 30 May 1997 and 13 July 2001. Upon our arrival at the study site several observers split up to search for the birds. Once 1 or more piping-guans were located, 2 or more observers coordinated their efforts to simultaneously observe and record several aspects of behaviour. The pipingguans were accustomed to humans passing daily through their home range and were generally unperturbed by our presence. Nevertheless, we attempted to avoid disturbing them by maintaining a discrete distance, yet we followed them as they moved through the forest and may have inadvertently disturbed them at times. During the study period we deployed several large-mesh $12 \mathrm{~m}$ mist nets to capture birds for radiotracking.

The locations of observed birds were plotted on a topographical map to calculate home range based on a minimum convex polygon. Group size was recorded during each hour of the day based on independent observations or sequential changes in group size (e.g. 1 if a single bird was observed, 3 if joined by 2 others, 2 if 1 flew away out of sight). We recorded the amount of time ( $\mathrm{min}$ ) each bird spent on the ground, in the understory or midstory $<5 \mathrm{~m}$ above the ground, or in the canopy $>5 \mathrm{~m}$ above ground. When foraging was observed we recorded the number of birds feeding and the species (if identifiable) and part (flower, fruit, or leaf) of the plant fed upon during each independent foraging bout on a specific plant. At $10 \mathrm{~s}$ intervals we recorded the behaviour of each individual, categorized as one of the following variables: perched alert, perched flapping wings, perched preening, walking, flying, feeding, and drinking. We described all displays observed, including their temporal occurrence and social context (i.e. solitary or grouped). We also recorded all interspecific interactions observed.

The range of time in which various behaviours were observed was calculated with respect to sunrise and sunset on the actual day of observation based on a calendar for Port of Spain, Trinidad, $52 \mathrm{~km}$ to the west (www.timeanddate.com). Because the data were collected repeatedly from the same individuals and often represented a time series, inferential statistical tests were not used.

\section{RESULTS}

\section{Group size and home range}

We spent $15 \mathrm{~d}$ unsuccessfully attempting to capture piping-guans Aburria pipile for radio-tracking, although on several occasions a piping-guan flew within a few metres of the mist nets. We accumulated $48.1 \mathrm{~h}$ of observations of individual piping-guans during $27 \mathrm{~d}$ (none were seen during several days of field work). Up to 6 different piping-guans were observed in the study area, but all were seen together only twice, on 31 December 1998 and 23 April 1999. All were of similar size and appeared to be adults. We observed no evidence of subgroups defending separate territories within the study site. The piping-guans were nearly always in smaller groups (often 2) or solitary, and often split up or joined together. Mean group size, based on independent observations or sequential changes within a given hour, varied from 1.5 to 2.5 during the day, with no clear pattern (Fig. 1). All piping-guans were observed at an elevation ranging from about 10 to $80 \mathrm{~m}$ within an area of $19 \mathrm{ha}$, which comprised their home range.

\section{Behavioural time budgets}

The piping-guans appeared to be active only during the early morning and late afternoon. Our morning sightings ranged from 05:53 to 09:03 h (2 to $192 \mathrm{~min}$ after sunrise), although 1 ind. was heard singing as late as 09:11 h (200 min after sunrise). Active birds that we easily observed and followed in the early morning invariably disappeared into dense forest canopy by 


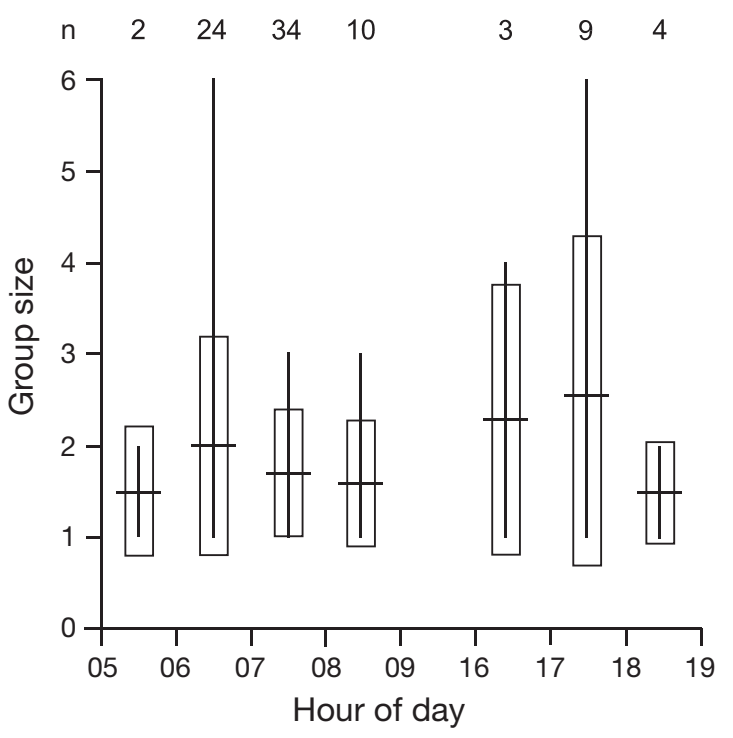

Fig. 1. Aburria pipile. Group size of the Trinidad piping-guan during different hours of the day. $\mathrm{n}=$ number of independent observations or sequential changes in group size. Horizontal line $=$ mean; vertical line $=$ range $;$ box $= \pm 1 \mathrm{SD}$

midmorning. After several days of searching unsuccessfully for piping-guans throughout the midday hours, we abandoned attempts to relocate birds after they disappeared in the morning and did not resume searches until midafternoon, after which they often reappeared suddenly. We observed the birds more consistently in the morning (about $95 \%$ of the time) than in the afternoon (about $50 \%$ of the time; our search efforts were inconsistently recorded). Our afternoon sightings ranged from 15:01 to 18:35 h (200 min before to $18 \mathrm{~min}$ after sundown). The activities of birds varied during hourly periods of observation (Fig. 2).

When active, birds were usually seen in the crowns of emergent trees, often at the edge of the forest, or flying between trees. In early morning ( $18.7 \mathrm{~h}$ of observation of individual birds), the piping-guans spent $80.3 \%$ of their time perched alert, 9.3\% preening, 3.9\% flying, $3.6 \%$ walking, $2.4 \%$ feeding, $0.3 \%$ drinking, and $0.1 \%$ perched flapping. In late afternoon $(8.2 \mathrm{~h}$ of observation), they spent $78.6 \%$ of their time perched alert, $12.8 \%$ preening, $3.7 \%$ walking, 3.0\% feeding, $1.2 \%$ flying, and $0.7 \%$ drinking.

Twice we observed piping-guans roosting for the night, once in a group and once alone. On 31 December 1998, 6 roosted together 6 to $9 \mathrm{~m}$ high in 3 closely spaced ornamental nutmeg trees (2 in each tree), where they were last seen at 17:45 h (10 min before sunset); they were still there at 06:42 h (47 min after sunrise) the following morning. On 4 April 1999, a singing bird appeared to be roosting alone about $10 \mathrm{~m}$ high in a wild nutmeg tree Virola surinamensis (Myristicaceae), where it was last seen in the dark at 18:38 h

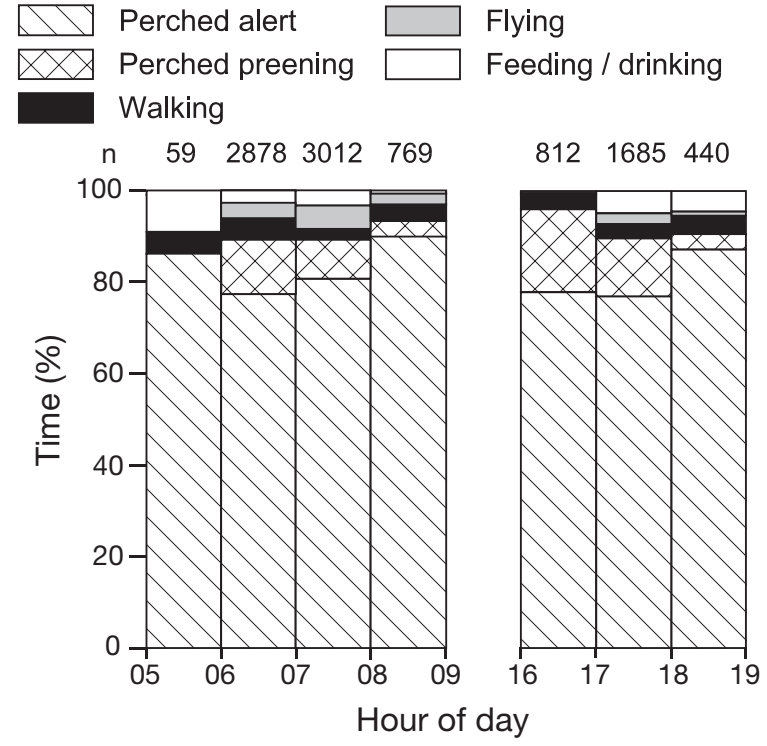

Fig. 2. Aburria pipile. Time budget of the Trinidad pipingguan during different hours of the day. $\mathrm{n}=$ number of observations of individuals recorded at $10 \mathrm{~s}$ intervals

(21 min after sunset); it was still there at 06:10 $\mathrm{h}$ (12 min after sunrise) the following morning.

The piping-guans spent $93.6 \%$ of the time in the forest canopy $>5 \mathrm{~m}$ above ground, $6.2 \%$ in the understory or midstory 0.1 to $5 \mathrm{~m}$ above the ground, and only $0.2 \%$ on the ground $(48.1 \mathrm{~h}$ of data based on individual birds), with little hourly variation (Fig. 3).

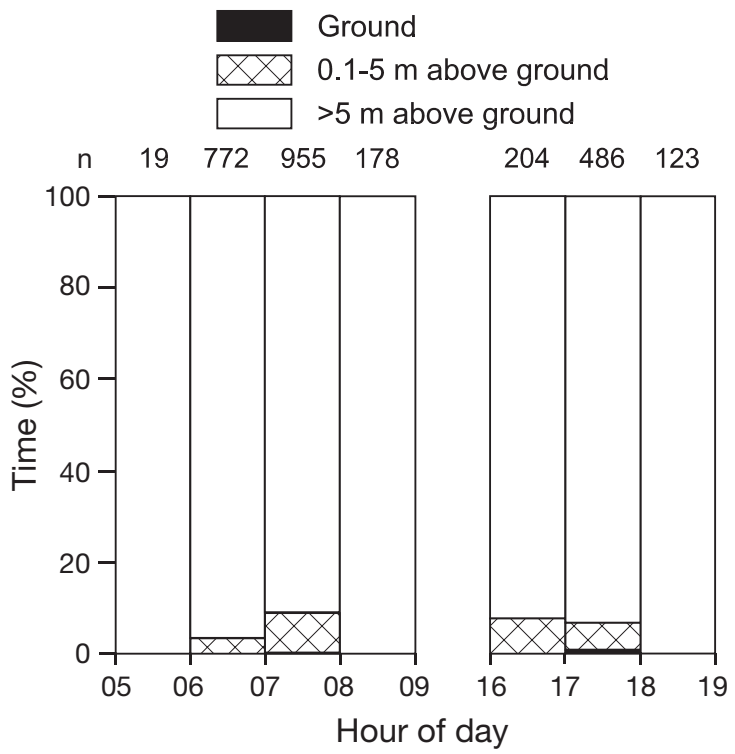

Fig. 3. Aburria pipile. Percent of time that Trinidad pipingguans spent at different vertical levels on the ground, in the understory or midstory ( 0.1 to $5 \mathrm{~m}$ above ground), or in the canopy ( $>5 \mathrm{~m}$ above ground). $\mathrm{n}=$ minutes of observation of individuals 


\section{Foraging and drinking}

Foraging occurred intermittently throughout the early morning and late afternoon, from 05:55 to $08: 15 \mathrm{~h}$ (11 to 152 min after sunrise) in the morning and from 16:50 to $18: 35 \mathrm{~h} \mathrm{(87} \mathrm{min}$ before to $18 \mathrm{~min}$ after sundown) in the afternoon. The piping-guans foraged solitarily half of the time and in small groups half of the time, with a mean of 1.8 birds foraging together $(\mathrm{SD}=$ 0.9 , range $=1$ to $4, \mathrm{n}=30$ independent foraging bouts of 1 or more birds feeding). The piping-guans foraged mostly on fruits (including budding fruits) and rarely on leaves or flowers of 15 species of plants, with fruits of Virola surinamensis constituting the primary food item $(33.3 \%$ of 30 foraging bouts; see Table 1$)$.

Twice we observed one bird feeding another: (1) a larger bird walking on the ground plucked the leaf of a vine and fed it to a smaller bird walking behind it; and (2) one bird fed another several times while the 2 were feeding on the leaves of a mango tree. It remains uncertain whether the recipient in each case was the offspring or mate of the provider.

On 10 occasions we observed a piping-guan drinking water from epiphytic bromeliads in the canopy of a tree. We did not observe piping-guans drinking water from any other source, including a stream near the edge of its home range.

\section{Displays and vocalizations}

Drumming displays, produced mechanically by the wings of a piping-guan gliding between 2 trees (see Alexander 2002), occurred intermittently throughout the early morning from $05: 55$ to $09: 01 \mathrm{~h} \mathrm{(11} \mathrm{to} 190 \mathrm{~min}$ after sunrise). We recorded only 1 drumming display in the afternoon, after a solitary bird sang for a few minutes at about 17:45 h (32 min before sunset). Drumming displays occasionally occurred during or after a bout of singing, and were given by both solitary and grouped individuals.

The piping-guan's song consisted of a series of 3 to 7 clear, plaintive, monotone whistles of a flute-like quality, each about $1 \mathrm{~s}$ long and $1 \mathrm{~s}$ apart, with succeeding whistles rising in pitch. Songs were always delivered by a lone bird perched high in a tree, although other birds were occasionally present in nearby trees, and often continued as the bird moved from one tree to another (up to 4 trees). During singing bouts an average of 2.7 songs were given per minute $(\mathrm{SD}=1.1$, range $=0$ to $4, \mathrm{n}=78)$. Singing occurred intermittently throughout the early morning and late afternoon hours, from 05:56 to 09:11 h (5 to 200 min after sunrise) in the morning and from 16:50 to $18: 15 \mathrm{~h}$ ( 87 to $2 \mathrm{~min}$ before sundown) in the afternoon. On one occasion a piping-guan sang fairly con-

Table 1. Plants (arranged alphabetically by scientific name) fed upon by the Trinidad piping-guan Aburria pipile, based on the number of observations in the present study and in Alexander (2002)

\begin{tabular}{|c|c|c|c|c|c|}
\hline Local name & Scientific name & Part eaten & $\begin{array}{c}\text { Present } \\
\text { study }\end{array}$ & $\begin{array}{c}\text { Alexander } \\
(2002)\end{array}$ & Total \\
\hline Wild tobacco (tree) & Acnistus arborescens (Solanaceae) & Fruit & 2 & 0 & 2 \\
\hline Vine (epiphyte) & Calopogonium coereleum (Fabaceae) & Leaf & 0 & 1 & 1 \\
\hline Cecropia (tree) & Cecropia (Cecropiaceae) & Fruit & 1 & 0 & 1 \\
\hline Wild caimite (tree) & Chrysophylum argenteum (Sapotaceae) & Leaf & 0 & 1 & 1 \\
\hline Redwood (tree) & Guarea trichilioides (Meliaceae) & Fruit & 3 & 0 & 3 \\
\hline Pois doux (tree) & Inga sp. (Fabaceae) & Fruit & 1 & 0 & 1 \\
\hline Wild potato (vine) & Ipomoea tiliacea (Convolvulaceae) & Leaf & 0 & 2 & 2 \\
\hline Mango (tree) & Mangifera indica (Anacardiaceae) & Fruit bud/leaf & 2 & 0 & 2 \\
\hline Ornamental nutmeg (tree) & Myristica fragrans (Myristicaceae) & Fruit & 3 & 11 & 14 \\
\hline Pomerac (tree) & Syzygium malaccense (Myrtaceae) & Fruit & 1 & 0 & 1 \\
\hline Teak (tree) & Tectona grandis (Verbenaceae) & Fruit & 1 & 0 & 1 \\
\hline Obie (tree) & Trichilia trinitensis (Meliaceae) & Fruit & 0 & 1 & 1 \\
\hline Wild nutmeg/cajuca (tree) & Virola surinamensis (Myristicaceae) & Fruit & 10 & 1 & 11 \\
\hline Fiddlewood (tree) & Vitex divaricata (Verbenaceae) & Fruit & 0 & 5 & 5 \\
\hline Bromeliad (epiphyte) & Unknown (Bromeliaceae) & Fruit & 1 & 0 & 1 \\
\hline Grass & Unknown (Poaceae) & Fruit & 1 & 0 & 1 \\
\hline 'Gualele' (tree) & Unknown & Flower/leaf & 1 & 0 & 1 \\
\hline 'Lapine' (tree) & Unknown & Fruit & 0 & 1 & 1 \\
\hline ‘Loeay carnel' (tree) & Unknown & Fruit & 1 & 0 & 1 \\
\hline Tree & Unknown & Fruit & 1 & 0 & 1 \\
\hline Vine (epiphyte) & Unknown & Leaf & 0 & 1 & 1 \\
\hline Vine (terrestrial) & Unknown & Leaf & 1 & 0 & 1 \\
\hline
\end{tabular}


tinuously for $30 \mathrm{~min}(08: 17$ to $08: 47 \mathrm{~h} ; 146$ to $176 \mathrm{~min}$ after sunrise), briefly interrupted by 3 drumming displays and terminating with a fourth drumming display.

A variety of soft piping calls, variable in length and pitch, and described by Alexander (2002) as 'peeoo' or 'pyoo', were often given. These were usually uttered during social interactions between nearby individuals, but occasionally were given by solitary individuals.

Piping-guans occasionally raised their crest. Twice we observed 2 birds facing each other with crests raised; on both occasions they uttered piping calls and then jumped at each other several times before separating. Once a piping-guan raised its crest while feeding with several birds in a tree. On another occasion a lone bird raised its crest once while singing for at least $19 \mathrm{~min}$, but no other piping-guan was seen nearby (although the displaying bird may have seen one), then it gave a drumming display when it flew away.

\section{Interspecific interactions}

The piping-guans rarely interacted with other species of birds. On 3 occasions we observed a pipingguan move from one branch to another when harassed intentionally or unintentionally by another species: once when a great kiskadee Pitangus sulphuratus dived at a piping-guan, once when 3 blacktailed tityras Tityra cayana flew at a piping-guan, and once when a blue-grey tanager Thraupis episcopus landed near a piping-guan. On one occasion 2 pipingguans flew into a tree, flushed a flock of orangewinged parrots Amazona amazonica, and then began feeding.

\section{Responses to human disturbance}

The piping-guans frequently displayed or foraged in trees when small groups of local farmers or visiting tourists walked along a nearby road, and did not appear to alter their behaviour in the presence of humans, even when talking loudly. When in the canopy of a tall tree they often tolerated us when we walked directly underneath, but sometimes they flew away as though they had been disturbed. In early 2000, local farmers cleared trees for gardens from an area of 3 to 4 ha and in another area of 1 ha within the home range of the piping-guans. The birds were no longer able to display or forage in areas which were cleared, yet the birds remained in the area and frequently flew across the open spaces.

\section{DISCUSSION}

\section{Group size and home range}

Alexander et al. (1990, 1992) and Alexander (2002) observed no more than 3 birds at a time in 1989 and 1991, which was only half the number of birds present during our study, but they were told by Leo Marin that up to 8 were present in 1990. Larger groups of up to 25 have been reported from elsewhere in Trinidad (James \& Hislop 1988, 1997). In both studies at Grande Riviere, piping-guans Aburria pipile were encountered both as solitary individuals and in small flocks, which often split apart or joined together. We suspect that a single group of piping-guans has occupied and defended a single home range in the area since the Marins first moved to the study site in 1963. Obviously there is frequent turnover in group size due to births, deaths, immigration, and emigration. Based upon average group size, the social structure of the Trinidad pipingguan appears similar to that of other species of pipingguans (Paccagnella et al. 1994, Olmos 1998, Guix et al. 2001, Wallace et al. 2001, Sánchez-Alonso et al. 2002).

Our estimate of 19 ha for the home range of a single group, based upon the assumption that all sightings of individuals at the periphery of the home range were of birds belonging to a single group, is the first such estimate for any species of piping-guan (Delacour \& Amadon 2004). Sightings reported by others from nearby areas of Grande Riviere (Hayes et al. in press) suggest that: (1) other groups of piping-guans occur in adjacent areas, (2) our focal group disperses farther than our observations suggest, or (3) satellite individuals occasionally disperse through the area. The extent to which different groups of piping-guans interact with each other is unknown. Obviously a more accurate estimate of home range could have been obtained from radio-tracking, but unfortunately we were unable to capture a bird in order to place a transmitter. Ideally the movements of multiple adjacent groups should be tracked with transmitters.

\section{Behavioural time budgets}

Our quantitative study of daily activity patterns represents the first for any species of piping-guan (Delacour \& Amadon 2004). In both studies at Grande Riviere, piping-guans were encountered more frequently in the morning than in the afternoon, suggesting that they are more active in the morning when they are easier to locate and observe. Because we were unable to encounter piping-guans between 09:03 and 15:01 h, we assumed that they roosted quietly in dense forest canopy during midday. This conclusion is supported by 
a solitary black-fronted piping-guan Pipile jacutinga monitored for $9 \mathrm{~h}$ in Brasil, of which $7 \mathrm{~h}$ were spent resting and preening while standing or sitting on folded tarsi (Paccagnella et al. 1994).

The Trinidad piping-guan clearly favours forest canopy during all periods of activity and only rarely descends to the ground to forage, a habit shared with other species of piping-guans (Delacour \& Amadon 2004).

\section{Foraging and drinking}

Our observations of foraging are similar to those of other piping-guan species that forage mostly on fruits, occasionally on leaves, and only rarely on flowers of a wide variety of plant species (Paccagnella et al. 1994, Galetti et al. 1997, Zent 1997, Delacour \& Amadon 2004). Sedaghatkish et al. (1998) listed 40 species of plants fed upon by Trinidad piping-guans, based on non-quantitative observations reported by James \& Hislop (1988), ffrench (1991), and Collar et al. (1992). Surprisingly we observed feeding on only 2 of these species, and Alexander (2002) observed feeding on only 3 of these species. Our study added 5 new species of identified plants to the known diet of the Trinidad piping-guan (Table 1). Alexander (2002) reported the fruit of the ornamental nutmeg Myristica fragrans (Myristicaceae) comprising $46 \%$ of the foraging bouts observed ( $\mathrm{n}=24)$, whereas in our study Virola surinamensis comprised $33.3 \%$ of the foraging bouts $(\mathrm{n}=30$; Table 1). These 2 species are clearly the favoured food items, comprising $46.3 \%$ of all foraging bouts when data from both studies are combined. Invertebrates including snails and insects have been reported in the diet of other species of piping-guans (Chebez 1990, Willard et al. 1991, Collar et al. 1992, Guzmán Almendras et al. 1999), but have yet to be confirmed for the Trinidad piping-guan, although hunters report that it occasionally forages for insects on the forest floor (James \& Hislop 1988).

Cracids, including piping-guans, have often been observed drinking water from streams (Delacour \& Amadon 2004). However, in our study, we observed piping-guans drinking water exclusively from epiphytic bromeliads, which apparently has not been previously reported for any other species of cracid (Delacour \& Amadon 2004). The only previous report is from James \& Hislop (1988, p. 22), who stated 'reports of direct drinking from epiphytes (wild pines) have also been received'.

\section{Displays and vocalizations}

The drumming displays and vocalizations of pipingguans are unique and have been studied more than any other behaviour exhibited by piping-guans (Delacour \& Amadon 2004). Those exhibited by the Trinidad piping-guan are similar to those of other species and were well described by Alexander et al. (1992) and Alexander (2002), who observed such behaviours only in the dark before 05:30 h. Our observations indicate that drumming displays and vocalizations are not limited to predawn darkness, but may occur throughout early morning and even during late afternoon periods of activity. Alexander et al. (1992) reported similar agonistic encounters between individuals in which the crest was raised, suggesting that raised crest feathers represent an aggressive or alarm display.

\section{Interspecific interactions}

Our limited observations of piping-guans interacting with other species suggest that they avoid direct encounters with small passerines. The instance when 2 piping-guans fed in a tree after flushing a flock of orange-winged parrots from it suggests they may have intentionally flushed competing frugivores from the tree.

\section{Responses to human disturbance}

Historically, hunting has been the greatest threat to the piping-guan's long-term survival, yet anecdotal accounts from hunters (James \& Hislop 1988, 1997) and our personal observations suggest that piping-guans are relatively unperturbed by human disturbance and quickly become habituated. Piping-guans are canopy frugivores and require tall forest trees for their survival. Although habitat destruction is clearly detrimental to the species, the present study demonstrates that the piping-guan tolerates limited human disturbances in small-scale agricultural plantations of rural communities as long as canopy trees are left intact in nearby forest and it is not hunted.

Acknowledgements. This study was generously funded by a grant from the St. Louis Zoo. We are especially indebted to Leo (deceased) and Theresa Marin, caretakers of the study site, for advice, encouragement, and assistance in locating birds and identifying food items. We thank D. M. Brooks and R. Inger for reviewing the manuscript; J. Anderson, M. Hayes, W. Hayes, J. Lucas, D. McNair, F. Murdoch, H. Nelson, I. Samad, B. Taylor, and K. Woods for assistance in the field; Y. Baksh-Comeau and D. Oatham of the National Herbarium, University of the West Indies, for assistance in identifying food items; and P. Bacon, D. Brooks, M. Macek, S. Temple, and J. O'Neill for advice and encouragement. The Lucas family of San Souci and P. Guerini of the Mt. Plaisir Hotel provided inexpensive lodging. 


\section{LITERATURE CITED}

Alexander GD (2002) Observations of the endangered Trinidad piping-guan (Pipile pipile), or pawi, in northern Trinidad. In: Hayes FE, Temple SA (eds) Studies in Trinidad and Tobago ornithology honouring Richard ffrench. Occ Pap 11, Department of Life Sciences, University of the West Indies, St. Augustine, p 119-130

Alexander GD, Brown L, Gilbert G (1990) Distribution and habits of the Trinidad piping guan. In: Downie R (ed) Report of the Glasgow University Exploration Society Expedition to Trinidad and Tobago, 1989. University of Glasgow, p 39-59

Alexander GD, Cunningham E, McCaul C, McCormack M (1992) Conservation-related observations of the Trinidad piping guan (Aburria pipile pipile). In: Downie $\mathrm{R}$, Reilly $\mathrm{M}$ (eds) Report of the University of Glasgow Conservation Expedition to Trinidad and Tobago, 1991. University of Glasgow, p 6.1-6.9

Chebez JC (1990) Los manuscritos de William Henry Partridge. Primera parte, aves misioneras 1. Nuestras Aves 22: $21-24$

Collar NJ, Gonzaga LP, Krabbe N, Madroño Nieto A, Naranjo LG, Parker TA III, Wege DC (1992) Threatened birds of the Americas. The ICBP/IUCN Red Data Book, 3rd edn, Part 2. International Council for Bird Preservation (now BirdLife International), Cambridge

Delacour J, Amadon D (2004) Curassows and related birds, 2nd edn. Lynx Edicions and American Museum of Natural History, Barcelona and New York

ffrench R (1991) A guide to the birds of Trinidad and Tobago. Cornell University Press, Ithaca, NY

Galetti M, Martuscelli P, Olmos F, Aleixo A (1997) Ecology and conservation of the Jacutinga Pipile jacutinga in the Atlantic forest of Brazil. Biol Conserv 82:31-39

Guix JC, Ruiz X, Jover L (2001) Resource partitioning and interspecific competition among coexisting species of guans and toucans in SE Brazil. Neth J Zool 51:285-297

Guzmán Almendras E, Brooks DM, Sedaghatkish G (1999) Natural history notes on the cracids housed in Museo Noel Kempff Mercado, Santa Cruz, Bolivia, with taxonomic notes on piping guans (Pipile). Bull Cracid Spec Group 8: 24-26

Hayes FE (2006) Trinidad piping-guan (Aburria pipile). In: Brooks DM (ed) Conserving cracids: the most threatened family of birds in the Americas. Misc Publ 6, Houston Museum of Natural Science, Houston, TX, p 32-34

Hayes FE, Samad I, Sanasie B (in press) Status and conserva-

Editorial responsibility: Michael Reed,

Medford, Massachusetts, USA tion of the Trinidad piping-guan Pipile pipile. Endang Species Res doi:10.3354/esr00184

James C, Hislop G (1988) Status and conservation of two cracid species, the pawi or Trinidad piping-guan (Pipile pipile) and the cocrico (Ortalis ruficauda) in Trinidad and Tobago. Forestry Division, Ministry of Food Production, Forestry and Environment, Trinidad

James C, Hislop G (1997) Status and conservation of the Trinidad piping guan or pawi (Pipile pipile). In: Strahl SD, Beaujon S, Brooks DM, Begazo AJ, Sedaghatkish G, Olmos F (eds) The Cracidae: their biology and conservation. Hancock House Press, Blaine, WA, p 242-247

Olmos F (1998) The Pipile cumanensis grayi-P. cujubi nattereri contact zone in Mato Grosso, Brazil. In: Brooks DM, Olmos F, Begazo AJ (eds) Biology and conservation of the piping guans (Aves: Cracidae). Cracid Specialist Group, Houston, TX, p 27-30

Paccagnella SG, Antonelli-Filho R, Lara AI, Scherer-Neto P (1994) Observacoes sobre Pipile jacutinga Spix, 1825 (Aves, Cracidae) no Parque Estadual de Carlos Botelho, São Paul, Brasil. Iheringia Sér Zool 76:29-32

Sánchez-Alonso C, Oliveras I, Martín M (2002) Density estimates of guans (Aves: Cracidae): Pipile jacutinga and Penelope obscura. In: Mateos E, Guix JC, Serra A, Pisciotta $\mathrm{K}$ (eds) Censuses of vertebrates in a Brazilian Atlantic rainforest area: the Paranapiacaba fragment. Centre de Recursos de Biodiversitat Animal, Universitat de Barcelona, Barcelona, p 67-78

Sedaghatkish M, Galetti M, Denny C (1998) The importance of Pipile as a seed disperser of economically important plants. In: Brooks DM, Olmos F, Begazo AJ (eds) Biology and conservation of the piping guans (Aves: Cracidae). Cracid Specialist Group, Houston, TX, p 4-12

Wallace RB, Painter RLE, Rumiz DI, Sainz L, Taber AB (2001) Comparative ecology of cracids in northern Dpto. Santa Cruz, Bolivia. In: Brooks DM, González-García F (eds) Cracid ecology and conservation in the new millenium. Misc Publ 2, Houston Museum of Natural Science, Houston, TX, p 68-86

Willard DE, Foster MS, Barrowclough GF, Dickerman RW and others (1991) The birds of Cerro de la Neblina, Territorio Federal Amazonas, Venezuela. Fieldiana Zool 65:1-80

Zent S (1997) Piaroa and the Cracidae: game management under shifting cultivation. In: Strahl SD, Beaujon S, Brooks DM, Begazo AJ, Sedaghatkish G, Olmos F (eds) The Cracidae: their biology and conservation. Hancock House Press, Blaine, WA, p 177-194

Submitted: April 24, 2008; Accepted: September 25, 2008

Proofs received from author(s): December 8, 2008 